\title{
POÉTICAS DEL HUMOR: DESDE EL NOVECENTISMO HASTA LA ÉPOCA CONTEMPORÁNEA
}

JosÉ ANTONIO LLERA

Universidad de Extremadura

En las páginas que siguen nos proponemos revisar algunas reflexiones modernas que ha merecido el concepto de humorismo en el ámbito de nuestras letras. No es nuestro objetivo mostrar la configuración expresiva que adquieren en la obra literaria de los autores - si es el caso- sus teorías, sino tan sólo buscar contrastes y concomitancias entre las distintas declaraciones programáticas.

\section{LOS NOVECENTISTAS}

\section{José Ortega y Gasset}

La deshumanización del arte (1925) de Ortega representa uno de los más tempranos y relevantes diagnósticos del arte nuevo español. Ortega sitúa la impopularidad del arte de vanguardia en la superación del concepto clásico de mimesis: «Lejos de ir el pintor más o menos torpemente hacia la realidad, se ve que ha ido contra ella. Se ha propuesto denodadamente deformarla, romper su aspecto humano, deshumanizarla» $(1925: 34)^{1}$. Se apuesta, entonces, por lo autorreferencial, lo intrascendente y lo lúdico. Ortega le dedica unas significativas palabras a la comicidad inherente al arte nuevo:

La comicidad será más o menos violenta y correrá desde la franca clownería hasta el leve guiño irónico, pero no falta nunca. Y no es que el contenido de la obra sea cómico [...], sino que el arte mismo se hace broma [...]. El artista de ahora nos invita a que contemplemos un arte que es una broma, que es, esencialmente, la burla de sí mismo (1925: 60-61).

\footnotetext{
${ }^{1}$ Esta superación se encuentra en la estela de la estética romántica. Vid. P. D’ANGELO (1997: 117-123).
} 
Nótese el adjetivo que le adjudica a la comicidad: se trata de una risa violenta, convulsa, como calificará después Breton a la belleza moderna, y que conceptualmente entraña autoironía y parodia, es decir, desdoblamiento del sujeto y práctica intertextual distanciadora. Continúa Ortega:

Si cabe decir que el arte salva al hombre, es sólo porque le salva de la seriedad de la vida y suscita en él inesperada puericia [...]. Todo el arte nuevo resulta comprensible y adquiere cierta dosis de grandeza cuando se le interpreta como un ensayo de crear puerilidad en un mundo viejo (63).

En el siglo veinte las vanguardias artísticas participan del sentimiento de liberación y de intrascendencia inherente al juego y le añaden el reactivo de la novedad, la sorpresa y la iconoclastia (R. Poggioli, 1962). La primera libertad es la que desliga al arte de la realidad para forjar su propio mundo. La vanguardia llena sus pulmones con el aire del optimismo, dice sí al deseo, a lo imaginario, a lo analógico; además, es contestataria e impugnadora de lo caduco. Trata de desautomatizar las convenciones asimiladas a la creación desde el Renacimiento y el Romanticismo, e introduce en sus composiciones lo absurdo, lo prosaico, lo conversacional, lo feo y aun lo escatológico. La puericia orteguiana representa bien a las claras dicha desinhibición.

\section{Ramón Gómez de la Serna}

La teoría humorística ramoniana, expuesta en «Gravedad e importancia y del humorismo» $(1928)^{2}$, tendrá una impronta imborrable en varias generaciones de escritores españoles, tanto vanguardistas como posvanguardistas. Desde el título, Ramón empieza haciendo una interesante matización: el juego vanguardista no es frívolo ni ligero, sino importante, grave ${ }^{3}$; so capa de lo trivial oculta un pensamiento hondo y subversivo sobre la experiencia y el mundo. Ramón parte de la teoría científica de los humores sólo como licencia para introducir el calibre de su ingenio: los glóbulos amarillos serían los glóbulos humorísticos, «que vienen a dar un sentido superior a la circulación, redimida de su crudeza, consolada de su seriedad, cohonestada su rigurosa fórmula» (1931: 198). El humorismo, como el carnaval (M. Bajtin, 1965), invierte jerarquías, introduce la paradoja, la mezcla, la escarpadura, lo imperfecto. Se pone necesariamente en

\footnotetext{
${ }^{2}$ El artículo será ampliado años más tarde para conformar «Humorismo», uno de los capítulos de Ismos (1931).

${ }^{3}$ Gómez de la Serna matiza las palabras de Ortega, que escribía: «El hecho no es que al artista [de vanguardia] le interesen poco su obra y oficio, sino que le interesan precisamente porque no tienen importancia grave y en la medida que carecen de ella» (1925: 62).
} 
guardia contra la voluntad de poder porque introduce el perspectivismo, la mirada multifocal y contingente sobre las cosas, la inteligencia de quien sabe que todo se lo lleva el tiempo. Ramón resalta su ambigüedad y su ambivalencia: «El humor muestra el doble de toda cosa».

El sesgo escéptico y melancólico del humorismo lo invalida para la sátira porque, al decir de Ramón, el humorista no trabaja con una idea de la concreta felicidad, sino que en su horizonte caben muchos mundos, la mayoría de ellos a medio hacer, otros a medio imaginar, todos efímeros en sus metamorfosis. El humorismo ni es género ni tropo literario, sino más bien actitud ante la vida, modalidad que atraviesa todos los géneros: «El humor, por ser tan extenso de significado, no puede ser considerado como un tropo literario, pues debe ser función vital de las obras de arte más variadas, sentido profundo de toda obra de arte» (201) ${ }^{4}$. Se ocupa después Ramón de los valores críticos y catárticos del humorismo, en unos párrafos de muy buena prosa cuya deuda con las teorías freudianas es evidente: «Sólo se puede soportar el tinglado de lo social gracias al humor, que desface idealmente lo que es irritante que esté tan hecho, tan uniformado, tan en estrados de entronización. El humorista es el gran químico de disolvencias, y si no acaba de ser querido y a veces se oponen a él duramente los autoritarios, es porque es antisocial, y al decir antisocial, antipolítico» (201-202). ¿Cómo no ver en el «desarmar lo alevoso» ramoniano la capacidad de desenmascaramiento que Freud (1905) le atribuye al humor?

En la segunda parte de su artículo, Gómez de la Serna medita sobre los ingredientes que componen esa milagrosa jalea real que es el humor. En este punto empiezan las anfibologías y cierta contradicción. La célula humorística se disocia en lo grotesco (hay ciertamente un Ramón macabrero), lo patético, lo bufo e incluso, para nuestra sorpresa, el sarcasmo. Decimos sorpresa porque si se da entrada al sarcasmo, que es la burla cruel (del griego $\sigma \alpha \rho \kappa i \zeta \omega$, 'desollar'), se expulsa en cambio de la república del humorismo - amén del chiste, el retruécano y la broma- a la burla, «que no cree en lo que dice y que cuenta con lo ridículo, impiedad de que carece el humorismo». También Ramón se muestra intransigente con la ironía: «La ironía tiene un deje francés y un tonillo ofensivo. Es un humorismo sin curar, al que falta la nota grave y profunda que hace perdonar el agravio» (210). La confusión está en asignar a una estrategia como la ironía. una sola intención, cuando sabemos por la pragmática que su fuerza ilocutiva puede ser muy diversa: el arco que va de lo puramente lúdico o lo ofensivo (L. Hutcheon, 1994: 47). Lo cómico tampoco sale mejor parado: «Lo cómico se verá siempre que ha sido un abuso y que ha aprove-

${ }^{4}$ Las teorías románticas, poderosamente subjetivizantes, influyen en esta concepción del humor como actitud ante la vida. Vid. J. P. RICHTER (1804). 
chado la indefensión y el azoramiento del que ríe» (211). Por último, Gómez de la Serna nombra a los que considera los tres embajadores históricos del humorismo: «Así Cervantes, Hurtado de Mendoza y, por fin, Quevedo, que lleva al laberinto de la ciudad, al baile de la Corte, el humorismo verdadero, enjundioso, con espesura, con profundidad» (223).

\section{Wenceslao Fernández Flórez}

En 1945 Fernández Flórez presenta «El humor en la literatura española» como discurso de recepción en la Real Academia Española. Al igual que ya había hecho la estética romántica, define el humor como «una posición ante la vida», y encarece la seriedad como algo conforme al espíritu humorístico. Según el auțor gallego, las tres actitudes esenciales del escritor ante el mundo serían la cólera, el lamento y la burla. A diferencia de otros grados de la burla como el sarcasmo o la ironía, el humor «es el tono más suave del iris. Siempre un poco bondadoso, siempre un poco paternal. Sin acritud, porque comprende. Sin crueldad, porque uno de sus componentes es la ternura. Y si no es tierno ni es comprensivo, no es humor» (1945: 32). El humorista se afilia entonces a la burla piadosa, pasada por el tamiz de la urbanidad. Las diferencias con la teoría ramoniana son acusadas, aun cuando ambos distinguen entre humor e ironía. Fernández Flórez estima que humor y sarcasmo representan polos opuestos, y que el humor es una de las especies —aunque balsámica- de la burla. Si nos detenemos a meditar los distingos de Fernández Flórez, hallamos de inmediato una semejanza grande con las ideas del filósofo psicologista alemán Theodor Lipps (muy divulgadas en España desde la traducción en 1923 de sus Fundamentos de la Estética) y con las tesis de Richter, que el autor gallego conocía probablemente por el capítulo que le dedica José Antonio Pérez Rioja (1942: 53-59) en su ensayo El humorismo. Lipps distingue tres grados de humor: el humorístico, el satírico y el irónico. La teoría de Fernández Flórez sólo atiende a la primera clase (el humor reconciliado en el esquema del teórico alemán), rechazando la sátira y la ironía. Como veremos, esta sinécdoque particularizante será norma en los teóricos españoles de posguerra. Fernández Flórez acopia aún más ideas próximas a la tradición romántica y anglosajona, como la melancolía o la sonrisa entre lágrimas. Debido a nuestro sentido trágico de la vida, en la literatura española sólo hay malhumor ${ }^{5}$; es el pueblo celta el que mayor predisposición muestra: «Una de las más viejas razas del mundo - la céltica- es la que ha producido en mayor número y más estimables escritores humoris-

\footnotetext{
${ }^{5}$ En este punto, concuerda Fernández Flórez con la tesis de UNAMUNo (1911), expuesta en su artículo «Malhumnorismo».
} 
tas. Irlandeses fueron Swift y Chesterton, Bernard Shaw y Oscar Wilde, en cuyas obras hay tan elegante y a veces tan enternecido humor» (35). Este elogio del humor celta provoca contradicciones insalvables en el inventario: el humor de Swift y de Wilde tiene, en efecto, mucho de elegante, pero es muy discutible su cariz tierno, sobre todo en el caso del primero (léase si no A Modest Proposal).

Conocido el discurso del escritor gallego, la pregunta es inevitable: ¿Por qué tamaña distancia entre los presupuestos teóricos y el espíritu satírico de buena parte de su obra? ${ }^{6}$ ¿A qué se debe el desajuste entre su tesis sobre el humor como ternura y el ingrediente urticante de Las siete columnas o de Relato inmoral? Según Evaristo Acevedo (1966: 233-238), el escenario conservador de la Real Academia y el régimen de censura previa impuesta por el régimen franquista hacían imposible una perspectiva crítica del humorismo. En todo caso; la lectura que practica Acevedo del discurso del autor gallego es apresurada, porque frente a la tesis esencial se despliega, sotto voce, como un hilván muy menudo, otra voz que no ha sido del todo reprimida por la autocensura. Inmediatamente después de definir el humor, Fernández Flórez sostiene que la actitud del escritor ante la vida está inspirada «más o menos secretamente por el descontento» (28), motor del progreso humano. El escritor no es ya el escéptico que decía Ramón, sino que su actitud convoca un proyecto trascendente: «Yo puedo decir de mí que cuando escribí Las siete columnas, El secreto de Barba Azul o El Malvado Carabel, no fue mi propósito hacer reír a alguien, sino combatir ideas que me parecían equivocadas» (27). El léxico agresivo que emplea para censurar las obras de Quevedo como no humorísticas lo encontramos, paradójicamente, aplicado a sus propias novelas. Uno de los últimos párrafos del discurso no puede ser más elocuente testimonio de las ideas de Fernández Flórez en cuanto a los valores correctores y lenitivos propios del humor, que lo colocan dentro de la tradición del sermo horaciano y muy próximo a las ideas de Bergson (1900):

Cuando el humor se debilita o desaparece pasa una sombra sobre la vida de los pueblos, porque es él quien la interpreta y la corrige con más afable simpatía, y quien nos sugiere las visiones con que encubrimos su fealdad, y hasta quien nos presta la sonrisa con que afrontamos muchos dolores inevitables $(48)^{?}$.

${ }^{6}$ Sobre la obra de FERNÁNDEZ FlóREZ puede verse: J. C. MAINER (1975) y C. FERNÁNDEZ (1987).

7 Julio CASARES (1945) contesta al discurso de Fernández Flórez, siendo el primero es categorizar correctamente el humorismo como una modalidad artística. A la ternura y la indulgencia que Fernández Flórez reconocía como ingrediente indiscutible del humor, el académico agrega una característica apuntada por RICHTER (1804): la generalización, la universalidad. Así se llega a la definición del humorismo como la quintaesencia de lo cómico, definición calcada del teórico alemán: «el humor es la interpretación sentimental y trascendente de lo cómico» (29). 
JOSÉ ANTONIO LLERA

\section{2. «LA OTRA GENERACIÓN DEL 27»}

En casi todos los autores del 27 el rasgo humor suele cruzar transversalmente algunas de sus creaciones. Como ha indicado César Nicolás (1983, II: 356-618), la greguería de Gómez de la Serna contagia a poetas y dramaturgos. Múltiples ejemplos pueden localizarse asimismo entre prosistas como Benjamín Jarnés, Juan Chabás, Max Aub, José Bergamín, Antonio Espina ${ }^{8}$ o Antonio Botín Polanco ${ }^{9}$. En un artículo dedicado a Jardiel, Laín Entralgo (1972) llamará «la otra Generación del $27{ }^{10}$ al grupo de escritores que ahondan con sus creaciones en lo humorístico, y para quienes Gómez de la Serna será el maestro indiscutible. Aparte de las coincidencias que presentan con el programa ramoniano (lo poético, para todos, sería inseparable del humor), las discrepancias van a girar en torno la comicidad y a la sátira como factores inherentes o espúreos del humorismo: Jardiel reivindica ambas; Mihura lo hará con reservas para la comicidad y rechaza la sátira; y Neville, introduciendo también matices en lo referente a la comicidad, destaca la sátira como humorística.

\section{Enrique Jardiel Poncela}

Aunque con inequívocos rasgos de ramonismo - la guillotina (ese martillo-pilón de la nobleza); detrás del espeso telón de boca de la niebla-, en Amor se escribe sin hache (1929) Jardiel se presenta como un escritor con estilo propio, con el barroquismo, el sarcasmo, la parodia y la inverosimilitud como rasgos más sobresalientes. En el prólogo de la citada novela dedica un breve capítulo al humorismo. Critica allí, con una frase que se ha hecho célebre, la costumbre de las definiciones: «Tratar de definir el humorismo es como pretender clavar por el ala una mariposa, utilizando de aguijón un poste del telégrafo» (93-94). Jardiel se sirve de la perspectiva múltiple para criticar al público que no entiende la verdadera naturaleza del humor y a aquéllos que lo tienen por un instrumento evasionista. El humorismo es «el padre de todo, puesto que es la esencia concentrada de

${ }^{8}$ Vid. su breve Lo cómico contemporáneo y otros ensayos (1928).

${ }^{9}$ Vid. su Manifiesto del humorismo (1951), dedicado a Gómez de la Serna, en donde afirma: «[El verdadero humorismo] no es un viento frío y despiadado, como la sátira. El verdadero humorismo mezcla a la burla, la ternura; al desdén por la miseria humana, la piedad por quien, habiendo sido capaz de soñarse tan alto, se resigna a caer tan bajo; sirve en una misma frase la risa y el llanto» (90).

${ }^{10}$ El marbete lo recoge José Luis LóPEZ RUBIO (1983), uno de los miembros de dicha generación, quien titula así su discurso de recepción en la Real Academia Española. Vid. M. ${ }^{a}$ L. BURGUERA y S. FORTUÑo (eds.) (1998). 
todo y porque el que hace humorismo piensa, sabe, observa y siente» (95). En el humor se anudan por tanto sentimiento y pensamiento, se trata de una visión integra de la realidad. En una digresión de carácter metadiscursivo, Jardiel vuelve sobre el asunto en la misma novela: «el humorismo iba a invadir la literatura, limpiándola de simpleza - porque el humorismo es el zotal de la literatura». Jardiel está convocando aquí los factores críticos y corrosivos de la modalidad cuando se asocia a la parodia, una estrategia capaz de desautomatizar los géneros literarios y de transgredir sus convenciones. Amor se escribe sin hache es, de hecho, un remedo de la novela sentimental, pues a juicio de Jardiel «las novelas 'de amor' en serio sólo pueden combatirse con novelas 'de amor' en broma» (98).

Pero es sin duda en el prólogo - escrito en 1933- que abre sus Obras completas donde expone con mayor extensión su poética humorística. Su lucidez radica en integrar lo satírico, en lo humorístico. Jardiel es un adelantado incluso a la hora de señalar la importancia del contexto, de la situación:

El humorismo no es una escuela: es una inclinación analítica del alma, la cual resuelve en risa su análisis. De ahí que en lo humorístico estén comprendidos lo irónico, lo sarcástico y lo satírico, con las naturales y propias diferencias de matiz de cada uno y aun de las circunstancias en que se produce cada uno (1963: 145).

Jardiel, a diferencia de Ramón y de Mihura, identifica humorismo y comicidad. Admirador de Muñoz Seca y de García Álvarez, pretende integrar la herencia grotesca, la caricatura, la sátira con el legado líricoingenuista de Ramón. De esta mezcla casi imposible resulta una escritura volcánica, que llega incluso a la autoparodia, de fuegos de artificio, entre el ingenio y lo chocarrero, recargada y desconcertante:

Lo cómico y lo humorístico no son conceptos antitéticos, como pretenden los pedantes, sino que, por el contrario, lo humorístico abraza muchas veces dentro de su órbita lo cómico. Y de ahí también el que lo cómico no sea siempre inferior, sino que tenga a menudo tanta calidad como lo humorístico, por parte integrante de un todo (ibidem).

Al contrario que noventayochistas como Unamuno (1911) o Baroja (1919), Jardiel no tiene ninguna duda de que Larra, Goya y Quevedo son humoristas, pues en el humor español predomina el espectro satírico, «no llora, sino que muerde». Para Jardiel, el humorismo es un fenómeno plural y universal; no está restringido ni en el espacio ni en el tiempo. De esta forma, pone en tela de juicio la sinécdoque particularizante que asocia el humorismo con Inglaterra:

El humorismo no es uno, único y sometido a leyes, ni es privativo de un pueblo, de una raza o un clima [...]. A ese humorismo inglés se refieren úni- 
camente, aunque crean referirse a todos, los que han caído en la manía de definir el humorismo como una escuela literaria y revelado el manoseado cliché de la 'lágrima oculta bajo la sonrisa' (146).

\title{
Miguel Mihura
}

La teoría humorística de Mihura se asemeja mucho a la propuesta ramoniana. El humor se identifica con la benevolencia, con la mirada inversa y polifocal. No obstante, cotejando las palabras de Mihura con las de Ramón, diríamos que en el programa de aquél está más diluido el potencial subversivo del humor. Ello puede explicarse por los factores históricos que actúan de filtro, esto es, la España de la posguerra. En un pasaje citadísimo y a menudo malinterpretado, afirma Mihura:

\begin{abstract}
El humor es un capricho, un lujo, una pluma de perdiz que se pone uno en el sombrero; un modo de pasar el tiempo. El humor verdadero no se propone enseñar o corregir, porque no es ésta su misión. Lo único que pretende el humor es que, por un instante, nos salgamos de nosotros mismos, nos marchemos de puntillas unos veinte metros y demos una vuelta a nuestro alrededor contemplándonos por un lado y por otro, por detrás y por delante, como ante los tres espejos de una sastrería [...]. El humor es verle la trampa a todo, darse cuenta de por dónde cojean las cosas; comprender que todo tiene un revés, que todas las cosas pueden ser de otra manera, sin querer por ello que dejen de ser tal como son, porque esto es pecado y pedantería. El humorismo es lo más limpio de intenciones, el juego más inofensivo, lo mejor para pasar las tardes. Es como un sueño inverosímil que al fin se ve realizado (1948: 304-305).
\end{abstract}

Junto al buen tono descansa una filosofía profunda y nada conservadora: «verle la trampa a todo», adoptar una mirada otra, desdoblarse dejando a un lado lo más gravoso del cuerpo, cuestionar el principio de identidad como había hecho ya la vanguardia. A diferencia del satírico, que parte siempre de una norma positiva, de un ideal definido de cómo deben ser las cosas, Mihura es más escéptico. No quiere cambiar el orden del mundo, lo cual no quiere decir que su propuesta no sea en su raíz transgresora, pues al presentar el envés de la realidad está poniendo en cuestión el mito de la unidad/necesidad sobre el que se sustenta toda ideología y todo poder. El desprecio de la sátira y de la ironía corre parejo al de Ramón: «Porque lo satírico y lo irónico es una válvula para la mala educación; es obra del mal genio, del rencor, de los celos y del resentimiento» (1966: 436). Mihura, más que mirar a la tradición de la sátira clásica o a los artículos de Larra, está pensando en la prensa satírica de principios de siglo, en la invectiva personalizada. Pérez Zúñiga, García Álvarez, Muñoz Seca, Antonio Paso y los dibujantes Xaudaró y Tovar integran según Mihura lo 
«auténticamente cómico, divertido, intrascendente, sin ninguna doble intención y sin buscarle tres pies al gato» (1966: 438). Sin embargo, mientras que en Jardiel los términos «comicidad» y «humorismo» se emplean como sinónimos, Mihura, siguiendo a Ramón, entiende que el humorismo representa una superación de la comicidad. En esa tradición tan castiza e hispana habría a su parecer más ganga que mena, por lo que era necesario pasarla por el cedazo de la modernidad vanguardista. En este caldo de cultivo se inscribe un proyecto como La Codorniz (J. A. Llera, I: 145-221).

\section{Edgar Neville}

Después de presentar a Quevedo y a Cervantes como los máximos embajadores de la prehistoria del humorismo hispánico, Neville coincide con Mihura: los orígenes del humor moderno se sitúan en Camba, Fernández Flórez y Gómez de la Serna, «que es como un remolino de alegría, de optimismo y de invención, y que, como no saben cómo calificarle, lo encierran dentro de la jaula de los humoristas (1969: 741). Todos ellos se alejan de la literatura festiva. Neville excluye de lo festivo las tragedias grotescas de Arniches: Es mi hombre, Para ti es el mundo y la Señorita de Trevélez, que él mismo llevará al cine. Para Edgar Neville el humor trasciende la literatura para convertirse en una manera de ser y de sentir (abarca tanto la estética como la ética), y se vincula al enfrentamiento contra algo, es dialéctico, busca la libertad:

\footnotetext{
El humor lo tienen ciertas personas, sobre todo si han tenido el valor de enfrentarse con las cosas de la vida sin la sumisión a las ideas hechas, a los valores reconocidos y a los lugares comunes aceptados. El humor es ironía y a veces sátira, es creer por entero, es respetar con reservas lo que los otros veneran incondicionalmente (1969: 739).
}

En otro de sus artículos, Neville insiste en el grado de desconfianza con respecto a los códigos establecidos que implica el humor. El rechazo del patetismo, de lo dramático (ya en Ortega) también es consustancial a una mirada que goza en lo contradictorio del mundo, en su contingencia, en su ironía: «[El individuo con sentido del humor] Es un espectador de todo lo que ocurre alrededor suyo, pero más dispuesto a encontrarle a las cosas y a las actividades el lado irónico que el dramático» (1969: 745). 


\section{ARTICULISTAS Y ENSAYISTAS EN LOS AÑOS SESENTA}

\section{Evaristo Acevedo}

Evaristo Acevedo fue uno de los más sagaces colaboradores de $\mathrm{La}$ Codorniz a partir de los años 50, fecha en que empiezan a publicarse dos de las secciones de mayor éxito en la historia del semanario: «La cárcel de papel» y «La comisaría de papel». A su ensayo Teoría e interpretación del humor español (1966) hay que reconocerle dos enormes méritos. El primero consiste en exponer de forma documentada una teoría clara sobre un concepto complejo. El segundo mérito - mayor si cabe- estriba en deshacer muchos de los tópicos disfrazados de verdades irrebatibles que se habían venido depositando en la escasa bibliografía española sobre la materia. Tales tópicos hacían soplar el viento del humor en una dirección única. Acevedo observa que el humor es universal y que consiste en la evolución del sentido antropológico del juego y de lo cómico (1966: 13). En efecto: vuelven las ideas de Jardiel treinta años más tarde, pese a que su nombre no aparece citado.

Acevedo hace un recorrido breve pero bastante solvente por las primeras manifestaciones de lo cómico en los principales países europeos, manifestaciones en su mayoría de carácter popular y anónimo. Con esa cartografía en la mano, acuña el concepto de protohumoristas para referirse al humor satírico previo al dominio en el continente del humor puro anglosajón: Rabelais en Francia (Gargantúa y Pantagruel); Brant en Alemania (La nave de los locos); los Diálogos y las Cartas de Aretino en Italia. En Inglaterra tampoco falta el espíritu crítico en Chaucer, en Swift o en Fielding. Acto seguido, analiza tres textos teóricos del ámbito hispano: el de Baroja (La caverna del humorismo, 1919) y los comentados de Fernández Flórez y Julio Casares. Los tres alimentan el tópico del humor como sentimiento de piedad, ternura y benevolencia hacia el objeto. Todos son contrarios a la sátira y a la ironía como manifestaciones humorísticas, y descartan la existencia de una tradición humorística española. A contrapelo, Acevedo demuestra que España está sobrada de tradición humorística e indica varios de sus hitos: Marcial, el Arcipreste, El Lazarillo, Cervantes, Quevedo, Larra y Goya.. Tras la tarea de demolición, Acevedo perfila sus tesis en la última parte de su ensayo: el humor es suprasocial e individualista, busca la libertad espiritual del individuo. La poética acevediana es la de un satírico reformista. Sostiene que la actitud ante la vida a la que debe responder el humorista radica en la crítica independiente de la intolerancia y de las estructuras sociales anquilosadas. Acevedo tiene claro que lo cómico es el elemento persuasivo necesario para que cale el mensaje crítico, y en eso funda su razón de ser. En suma, reedición del topos horaciano de la verdad con burlas: 
El humorista acude a lo cómico para popularizar y hacer más comprensible la filosofía que expone [...]. El humor es la dignificación de lo cómico. Pero si puestos a 'dignificar' abominamos de lo cómico para conseguir una dignificación del humor, reduciremos a éste a la nada; al cero absoluto. Ahora bien: cuando partiendo de lo cómico sólo se busca la risa, sin finalidades pensativas posteriores, no hay humor (282).

Es la última frase la que nos parece más discutible en relación con la teoría que ha venido exponiendo en páginas posteriores. Acevedo ha abierto - con razón - el humor al ámbito de lo satírico, clausurado por las interpretaciones parciales de las teorías románticas; y sin embargo, termina su estudio sellando al humor en la cripta de lo satírico: todo lo cómico que no se vincule a una intención reformadora no adquiere la categoría superior de humor. Su defensa de la risa se justifica sólo en virtud de su carácter persuasivo, mientras que paga con la misma moneda, con el desprecio, a otras categorías históricas del humor (no sólo la línea romántico-sentimental, sino, por ejemplo, el arte verbal del barroco o el humor puro vanguardista).

\section{Santiago Vilas}

Acevedo le había puesto a lo cómico la condición de lo crítico-trascendente para alcanzar la cota de lo humorístico. Santiago Vilas, por su parte, emplea humorismo para denominar a la sublimación o intelectualización del humor, así como para referirse a una escuela, doctrina, filosofía o estilo; y propone el neologismo de humoricidad como «calidad de humor en su aspecto no artístico, más vulgar, humor chistoso, jocoso, desprovisto de las inquietudes filosóficas o estéticas, de la trascendentalidad, que mueven hacia el humorismo» (1968: 41). Ni que decir tiene que su teoría no es fruto de una meditación diacrónica, sino que se centra en la modernidad, en una relectura de las doctrinas románticas, recogidas en el entonces reciente ensayo de Celestino Fernández de la Vega, $O$ segredo do humor (1963).

El sistema de Vilas no nos parece acertado porque mezcla categorías lingüísticas o genéricas con categorías estéticas y morales. En su genealogía coloca a la diestra a los hijos legítimos del humor: humorismo, greguería, ingenio...; y a la siniestra a los bastardos o desnaturalizados: humoricidad, broma, burla, parodia... También hay sitio para una prole híbrida. Se desplaza a la sátira y a la ironía a un lado u otro del tronco central del humor según su intención «buena» o «mala»: la sátira y la ironía agresivas hacia la degeneración del humor, esto es, hacia la humoricidad o hacia el sarcasmo. Lo adecuado hubiera sido hablar, acudiendo a la pragmática, de intención lúdica y de intención agresiva, sin ninguna connotación mo- 
ral adyacente. Ésta es la perspectiva que Santiago Vilas quiere aplicar en su estudio:

El humor se exterioriza tanto en la literatura como en todo el arte en general [...]. Y hay que analizarlo y clasificarlo según la técnica de expresión: novela, ensayo, comedia, chiste, etc.; y según la calidad resultante y la intencionalidad del humorista: humorismo, humoricidad, ironía, sátira, sarcasmo, burla, parodia... (46).

El inventario es harto caótico: a los géneros - novela, comedia...- se los denomina «técnicas»; se mezclan estrategias retóricas como la ironía o intertextuales como la parodia con modalidades como el humor o la sátira (género sólo en Roma). Vilas diferencia humor y humorismo (éste la sublimación de aquél), aun cuando esta diferencia no se justifica ni etimológica ni lexicográficamente. Tres son los rasgos que en su opinión singularizan al humorismo: intrahistoricidad, perspectivismo y escepticismo. El primer rasgo se emparenta con el principio de subjetividad de Richter y con el Einfühlung de Lipps (principio de proyección del yo en el otro): «Experimento placer al escaparme de mí, al sentir en mí lo otro, y viceversa, al sentirme yo en lo otro, al experimentar la consciencia de que soy en mí y en lo demás al mismo tiempo, simultáneamente» (59). El perspectivismo se define como el necesario movimiento de retorno desde la subjetivización del objeto: «[...] el humorista subjetiviza, se liga y funde con la cosa al mismo tiempo que es en sí mismo; pero después tiene que reobjetivizar y además ocupar simultáneamente las tres posiciones: ser en sí mismo, en la cosa, y en un hipotético tercer lugar desde el cual va a ver» (60). El escepticismo, del que también hablaba Gómez de la Serna, nace de la insatisfacción y el desengaño lúcido que invade al humorista tras la búsqueda de la perfección y de la belleza. En el planteamiento de Vilas este concepto se encuentra cercano a la ironía romántica, salvo en el hecho de que para él se trata de un «escepticismo optimista» (56).

La confusión de las tesis expuestas creemos que estriba en la equivocada elección del elemento matriz: el humor. Vilas resalta como constituyentes esenciales de éste la benevolencia, el talento, la tolerancia, la sutileza o la humanidad. Sin embargo, esta categorización del humor pertenece sólo a una interpretación de las teorías germanas herederas del romanticismo, las primeras que en la modernidad reflexionan sobre el concepto. Pensamos que la raíz habría que buscarla no en el humor, sino en el género histórico de la comedia o, en sentido lato, en el juego y la fiesta, orígenes a su vez de aquélla (A. Pickard-Cambridge, 1968; F. Rodríguez Adrados, 1983). Para Vilas la comicidad pertenece al campo semántico del ridículo, la malicia y la burla, hecho que la distancia notablemente del concepto de humorismo (o sublimación del humor), de ahí que necesite de 
malabarismos poco convincentes para intentar poner en claro las relaciones entre comedia y humor:

La comedia necesita el humor, es uno de sus ingredientes más importantes, indispensables; pero, por su parte, la comicidad no podrá nunca formar parte del humor puro, de la obra humorística pura. Es una cuestión de origen. La comicidad es un derivado del humor, uno de sus varios hijos; como el humorismo (70).

\section{LA REFLEXIÓN SOBRE EL HUMOR EN LAS ÚltiMAS DÉCADAS: JOSÉ ANTONIO MARINA ${ }^{11}$}

José Antonio Marina reúne méritos como para encontrarse entre los mejores ensayistas españoles del momento. Su puesta en práctica de un discurso interdisciplinar lo hace distinto a muchos filósofos o eruditos, atrincherados en las catacumbas de su especialidad. Marina pasa por la linguística, la retórica, la filosofía, las ciencias de la computación, la psicología, la antropología y demás disciplinas con agilidad y elegancia. Todas estas virtudes no empecen para que mostremos un serio desacuerdo con las tesis que expone en su celebrado primer libro, Elogio y refutación del ingenio (1992), donde empieza por delimitar lo que le parecen los rasgos capitales del ingenio: sorpresa, fecundidad, rapidez, eficacia, brevedad, equívoco, juego. Así constituido, el ingenio es «el proyecto que elabora la inteligencia para seguir jugando» (1992: 23). Su rasgo definitorio sería la devaluación de la realidad, que proporciona al ingenioso una suerte de eufórica «libertad desligada». Éste sería el signo de su elogio, porque libera, y también el de su refutación, porque aniquila.

Aunque Marina acierta plenamente al catalogar al ingenio como una de las especies del juego, éste puede ir más allá de un mero narcisismo devaluador, se puede uncir a un proyecto trascendente. Marina tiene en mente ciertas bromas hueras del arte moderno y no la tradición española del mejor humorismo satírico, de ahí su insistencia en el nihilismo inherente a la risa: el sujeto que se desliza por la pendiente del ingenio acabaría devaluado por el efecto letal de las paradojas pragmáticas que permanecen disimuladas en dicho movimiento. En cuanto a la ironía no la ve como un saludable ejercicio de la inteligencia, sino como arma de combate, como deconstrucción de toda ley de pensamiento, como «reflexión roedora» (206). Su mirada se concentra sólo en la negatividad infinita de la ironía que ya han reseñado otros autores (W. C. Booth, 1974: 290-344;

\footnotetext{
"Además del libro de José Antonio MARINA (1992), merecen reseñarse, entre otros, los trabajos de Néstor LUJÁN (1973), Gonzalo ABRIL (1989), Valeriano BOZAL (1989) y Jorge LARROSA (1995).
} 
P. de Man, 1981: 231-253), descuidando valores estéticos (y éticos) relevantes. Tampoco la parodia escapa al vapuleo:

La parodia, que tanto ha interesado a los modernos, es una técnica liberadora. Nos faculta para adquirir una doble voz, con lo que las cosas adquieren una duplicidad que Bajtin considera enriquecedora, pero que no lo es. La parodia devalúa siempre. Por eso es una técnica ingeniosa (190).

Todo ello es muy discutible, porque en toda parodia hay un momento de mimo y de homenaje que la hacen ser al mismo tiempo transgresora y conservadora del texto al que parodia (L. Hutcheon, 1985). Paradoja que no sabe ver Marina. A la sátira también se la juzga por el mismo rasero:

Es sin duda en la sátira en donde aparece con mayor nitidez el doble efecto del ingenio: devaluar la realidad y fortalecer el yo. Es un juego cruel, que evita, sin embargo, la acćión violenta. La sátira, la burla, el ingenio verbal son eficaces armas de una agresividad intelectualizada. Convierten al enemigo en juguete, al que zahieren sin grosería, porque el insulto está transfigurado por el dominio, la novedad y la gracia» (96-97).

Nos quedamos en la pólvora de la sátira sin profundizar en su proyecto. La reflexión se inserta dentro de la perspectiva freudiana y de las llamadas «teorías de la superioridad», es decir, el Platón del Filebo (48e50d) y el Hobbes (1651) del Leviatán. Independientemente de que Marina no diferencie entre sátira e invectiva, quintaesencia lo psicológico y olvida buena parte de los factores retóricos, poéticos e incluso éticos que hacen de cierta sátira una fantasía comprometida, y por tanto, un juego serio, una tarea no exenta de gravedad, donde el ingenio ya no es autorreferencia vacua sino crítica de las arbitrariedades del poder. ¿Y podríamos catalogar ese juego que rinde cuentas con la realidad como un timo devaluador?

\section{CONCLUSIONES}

En casi todos los textos se detectan ambigüedades y contradicciones a la hora de evaluar los vínculos entre la comedia, el humor, la sátira y la ironía. En general, al menos hasta los años cuarenta, la polémica se centra en dos visiones del humor: una idealista y otra deshumanizada. Hay que tener muy en cuenta que el contexto histórico del franquismo hace de filtro de un humor disolvente, crítico, incongruo que aparece en los manifiestos artísticos y en el arte de vanguardias desde los años veinte, sea estrictamente satírico o no. La reacción contra la estilización caricaturesca, la sátira y lo grotesco supone el encarecimiento el humor benevolente o idealista, sea de linaje cervantino o se identifique con el de los novelistas ingleses. También resulta muy acusado el mimetismo que con relación a 
las teorías románticas presentan casi todos los autores, a excepción de Jardiel Poncela.

En los años sesenta, el ensayo de Evaristo Acevedo Teoría e interpretación del humor español (1966) revisa desde presupuestos distintos las teorías precedentes, las cuales, no obstante, todavía cuentan con continuadores en el ámbito de la crítica literaria como Santiago Vilas (1968). Por otro lado, el libro de José Antonio Marina, Elogio y refutación del ingenio, ya en los años noventa, vino a cubrir un vacío en la ya muy irregular ensayística española sobre esta materia, si bien la tesis que plantea es bastante discutible, puesto que si bien es cierto que el humor puede invalidar la crítica, también la hace posible.

\section{REFERENCIAS BIBLIOGRÁFICAS}

ABRIL, G. (1989), «De la comicidad al humor», La Balsa de la Medusa, 10-11, pp. 13-22. ACEVEDO, E. (1966), Teoría e interpretación del humor español, Madrid, Editora Nacional.

BaJTIN, M. (1965), La cultura popular en la Edad Media y Renacimiento, Barcelona, Seix Barral, 1974.

BARojA, P. (1919), La caverna del humorismo, Madrid, Caro Raggio, 1986.

BERGSON, H. (1900), La risa. Ensayo sobre la significación de lo cómico, Valencia, Prometeo, s.d.

Booth, W. C. (1974), Retórica de la ironía, Madrid, Tuarus, 1986.

Botín Polanco, A. (1951), Manifiesto del humorismo, Madrid, Revista de Occidente. Bozal, V. (1989), «La lucidez de la risa», La Balsa de la Medusa, 10-11, pp. 53-67. BURguera, M." L. y FortuÑo, S. (eds.) (1998), Vanguardia y humorismo: la otra Generación del 27, Castelló de la Plana, Publicacions de la Universitat Jaume I.

CASARES, J. (1945), "Concepto del humor», en Obras completas, IV, El humorismo y otros ensayos, Madrid, Espasa-Calpe, pp. 21-48.

D’ANGelo, P. (1997), La estética del romanticismo, Madrid, Visor, 1999.

EsPinA, A. (1928), Lo cómico contemporáneo y otros ensayos, Madrid, Cuadernos Literarios.

FERNÁNDEZ DE LA VEGA, C. (1963), O segredo do humor, Vigo, Galaxia (Trad. española: El secreto del humor, Buenos Aires, Nova, 1967).

FERNÁNDEZ FLóREZ, W. (1945), «El humor en la literatura española» [Discurso de recepción en la RAE], en Obras selectas, Barcelona, Caro Raggio, 1979, pp. 21-49.

FERNÁNDEZ, C. (1987), Wenceslao Fernández Flórez: Vida y obra, La Coruña, Diputación Provincial.

FREUD, S. (1905), El chiste y su relación con lo inconsciente, Madrid, Alianza, 1969.

GÓMEZ DE LA SERNA, R. (1928), «Gravedad e importancia del humorismo», Revista de Occidente, 28 de febrero, pp. 348-360.

- (1931), «Humorismo», en Ismos, Madrid, Guadarrama, 1975, pp. 197-233.

HoBBES, T. (1651), Leviatán, Madrid, Editora Nacional, 1983.

HutChEON, L. (1985), A Theory of Parody. The Teachings of Twentieth-Century Art of Forms, Londres, Methuen.

- (1994), The Edge of Irony, Toronto, Oxford University Press.

JARDIEL PONCELA, E. (1929), Amor se escribe sin hache, ed. de Roberto Pérez, Madrid, Cátedra, 1999. 
- (1963), Obras completas, Barcelona, AHR, 5 vols.

LAín ENTRAlGO, P. (1972), «El futurismo irónico de Jardiel», La Gaceta Ilustrada, 28 de mayo, p. 15.

LARROSA, J. (1995), «Elogio de la risa o de cómo el pensamiento se pone, para bailar, un gorro de cascabeles», Aprender a pensar, 11, primer semestre, pp. 43-57.

LIPPS, Th. (1923), Los fundamentos de la Estética, Madrid, Daniel Jorro.

LÓPEZ RuBIO, J. (1983), La otra Generación del 27 [Discurso de recepción en la RAE], Madrid, Real Academia Española.

LuJÁN, N. (1973), El humorismo, Barcelona, Salvat.

LlerA, J. A. (2000), Sátira y humorismo: el caso de La Codorniz (1956-1965), Cáceres, Universidad de Extremadura, 2 vols. (Tesis doctoral).

MAINER, J. C. (1975), Análisis de una insatisfacción: las novelas de W. Fernández Flórez, Madrid, Castalia.

MAN, P. de (1981), «Retórica de la temporalidad», en Visión y ceguera: Ensayos sobre la retórica de la crítica contemporánea, Editorial de la Universidad de Puerto Rico, 1991, pp. 207-253.

MARINA, J. A. (1992), Elogio y refutación del ingenio, Barcelona, Anagrama.

MinurA, M. (1948), Mis memorias, Madrid, Temas de Hoy, 1998.

- (1966), «Periodismo de humor», en GonZÁlez RuIZ, N. (ed.), Enciclopedia del periodismo, Barcelona-Madrid, Noguer, 1980, pp. 435-449.

Neville, E. (1929), Don Clorato de Potasa, ed. de M. ${ }^{a}$ L. Burguera, Madrid, EspasaCalpe, 1998.

- (1969), Obras selectas, Madrid, Biblioteca Nueva.

Nicolás, C. (1983), Ramón Gómez de la Serna y la Generación del 27, Cáceres, Universidad de Extremadura, 3 vols. (Tesis doctoral).

ORTEGA Y GASSET, J. (1925), «La deshumanización del arte», en La deshumanización del arte y otros ensayos, Madrid, Ediciones de la Revista de Occidente, 1970.

PÉreZ RiojA, J. A. (1942), El humorismo, Barcelona, Salvat.

PiCKARD-CAMBridge, A. (1968), The Dramatic Festivals of Athens, Oxford, Clarendan Press.

Platón (1992), Diálogos: Filebo, Timeo, Critias, ed. y traducción de M$^{\text {a }}$. A. Durán y F. Lisi, Madrid, Gredos.

Poggioli, R. (1962), Teoría del arte de vanguardia, Madrid, Revista de Occidente, 1964. RICHTER, J. P. (1804), Introducción a la Estética, Madrid, Verbum, 1990.

RodríGUEZ Adrados, F. (1983), Fiesta, comedia y tragedia, Madrid, Alianza.

UNAMUNO, M. de (1911), «Malhumorismo», en Soliloquios y conversaciones, Madrid, Renacimiento, pp. 107-115.

VILAS, S. (1968), El humor y la novela española contemporánea, Madrid, Guadarrama. 